\title{
NET CONSUMER OF RICE AND POVERTY IN INDONESIA: SIMULATION USING EQUIVALENT VARIATION
}

\author{
Wiena Maulidia Respati ${ }^{1}$, Witra Ghaitsa Gafara ${ }^{2}$, Ridho Al Izzati ${ }^{3}$ \\ 1,2,3 Faculty of Economics and Business, Padjajaran University
}

Email: winnamaulidia@gmail.com, ghaitsah@gmail.com, ridhoalizzati@gmail.com

\begin{abstract}
Indonesia's domestic rice price has experienced a significantly increase when the global price of corps commodity decline. An increase in rice price from 2012 to 2015 had reached 30\%. The most acute occurred on the first quarter of 2014 until the last quarter of 2015 that overtake 17\%. Increase in domestic rice price will affect mostly to consumer welfare in Indonesia, because as we know, rice is one of the staple food for Indonesian people whom has inelastic demand. This paper uses National Socioeconomics Survey (SUSENAS) year 2012 and 2014. We revisit McCulloch (2008) and used SUSENAS 2004 to calculate amount of agricultural household in Indonesia. The result of the author's calculation there was a diminution from $46 \%$ in 2004 to $37 \%$ in 2012 on the amount of agricultural households in Indonesia. From the total of agricultural household, $19 \%$ are the rice-farming households. Surprisingly, $90 \%$ of Indonesia's households are the net consumer whom bought the rice from the market. The result shows that $15 \%$ of the total net consumers are the rice-farming households and $10 \%$ of net consumers are poor households. This means that if there is an increasing in the price of rice, automatically this household will get influenced include the rice farmers who in fact is also as the rice producers.

The authors conduct simulation to see the effect of the increase in the rice price towards consumptions that ultimately will alter poverty incidence. Simulation that has been performed uses equivalent variation method to calculate a changing on household consumption as the result of an increase in the rice prices. The result from the simulation of a increase in rice price shows that households in every quantile is affected, ceteris paribus. Authors also including Raskin as compensated consumption when there is an increase in rice prices. These findings suggest that, rice price should be stabilized in order to maintain the society's welfare and government should establish pro-poor policy especially for food security to prevent the increasing of poverty incidence.
\end{abstract}

Keywords: rice price, poverty, rice farmer, equivalent variation JEL Code: $132, Q 18$

\section{INTRODUCTION}

"Growth by expenditure: Exports still contracting. Investment and government consumption were the dominant factors. Private consumption is at a record low. Big import contraction." From that statement, even though the largest proportion of Indonesia's GDP is consumption, Indonesia experienced a 
negative change in consumption. What are the factors that lead consumption of Indonesian people decreasing?

One of several factors that influence a decreasing in consumption is inflation on food price. In early 2015 food price is increasing and it fluctuating until late October 2015 and rice is the most significant. Price of staple food for most of Indonesian is reported to have increase by $17 \%$ in the last six months. In fact, Indonesia is the third largest rice producer with total production 70.8 million tons per year.

Figure 1 Trend of Rice Price 2012.1-2015.3

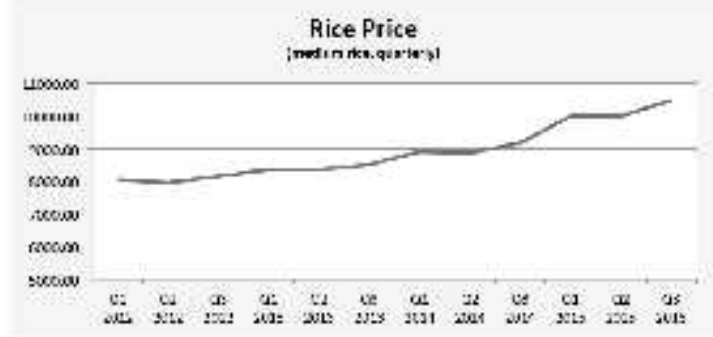

Source: Ministry of Agriculture Rep of Indonesia (2016)

From Figure 1 above, the price of medium rice keep on increasing from year 2012-2015.

Table 1 Change of Rice Price 2012.1-2015.3

\begin{tabular}{|c|c|c|c|c|}
\hline & & Triec change grarly. & 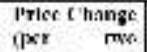 & \\
\hline Unarier & Matic & & & challye \\
\hline 0120.2 & 8950.37 & & & \\
\hline Q $2 \mathrm{ma}^{2}$ & 983498 & $1.2 \times 4$ & & \\
\hline game & $8157 x$ & & & \\
\hline (3) 20 & $22 i>32$ & & $=8.000$ & \\
\hline $0 \times n=$ & $22 \mathrm{Ci} 77$ & 1,7958 & & \\
\hline $03200=$ & 3559.14 & & & $20 \operatorname{sen} x_{u}$ \\
\hline Q1 200: & 30032.5? & & & \\
\hline 022014 & sekins & $2, x x^{2}$ & & \\
\hline (1) 20052 & $91-5.12$ & & & \\
\hline Q1 $201 \mathrm{~s}$ & $003,5,5$. & & $1310-40$ & \\
\hline 022016 & 5003.67 & 4.546 & & \\
\hline $0: 2 m e$ & $047 \ldots . .5$ & & & \\
\hline
\end{tabular}

Source: Ministry of Agriculture Rep of Indonesia (2016)
Increasing in the price of rice is resulting on economic flaming, especially for poor people. Moreover, the price of rice is inelastic so a significant increasing in their price won't change much on the public consumption. A rise in the price of goods will make the consumption of that goods decreasing, but not for rice. People tend to consume less on other goods because the portion of rice consumption needs to be increased. An increase on the rice price is followed by an increase in labor nominal wage, but that does not change anything on their real wage.

\section{THEORETICAL FRAMEWO-RK AND HYPOTHESES \\ Agriculture Challenge in Indonesia}

Government argues that an increasing in the price of rice is occurred because they want to protect farmers and reduce the number of poverty, especially those who lives in the rural area. They believe that benefits of increasing in the price of rice will affect directly for the poor. This happens because government assumes that most of poor people in the rural sector depend on agricultural sector, mainly rice production. Then an increase of it is considered to have a direct impact of increasing wage that farmers can get. McCulloch however, show us that in the real life, that supposition is less precise. Most of farmers produce less amount of rice than their own consumption of it. An increase in the price of rice will also damage the farmer itself. One party that gets a lot of benefits from an increasing on the price of rice is those farmers who produce more and consume less rice. In addition, landlords contribute to get a huge benefit from an increasing of the price of rice. 


\section{Employment in Indonesia}

Rice is the most important commodity for household income, especially farmer household itself. On table 3 , we can see type of works and welfare status of labors in Indonesia. The number of rice farmers in Indonesia on 2012 is $17.84 \%$ of the total number of Indonesian workers. $34.05 \%$ of rice farmers are poor household and $15.84 \%$ is nonpoor poor household. This number is the largest amount of household of all economic sectors in Indonesia. Around $15 \%$ of poor households that live in urban area are farmers. Meanwhile, $43.17 \%$ of poor households in rural area are also farmers. Only $5.26 \%$ of all sectors in urban area are non-poor farmers, while in rural area only $26.64 \%$ non-poor farmers.

Table 2 Adult Employment and Poor Status

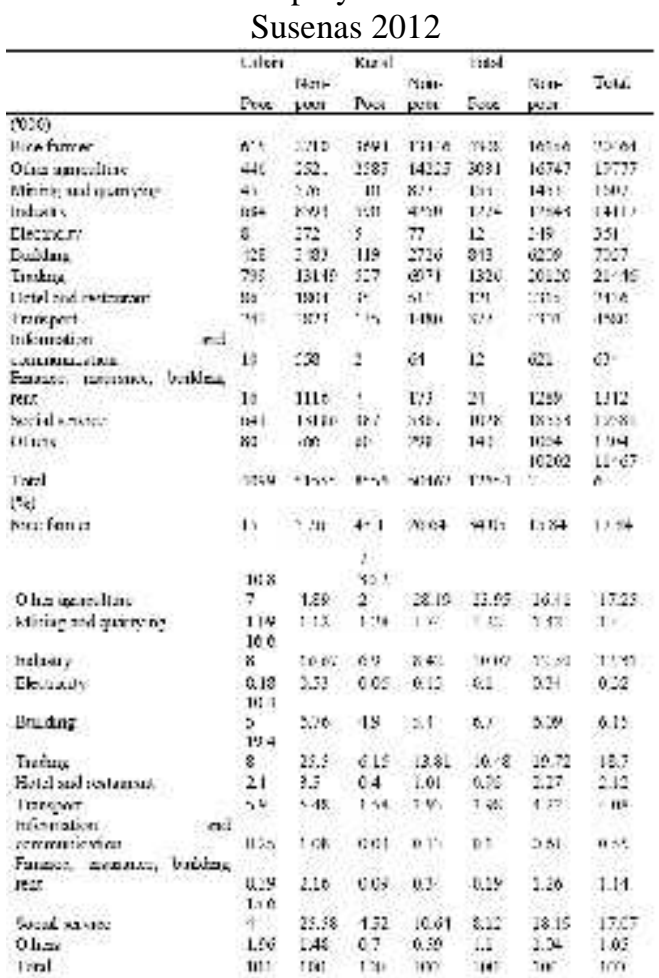

Source: Badan Pusat Statistik (2012)

Table 2 shows the relation between economic status and work field in rural and urban on 2012. The most interesting part is the result from rural, most of poor household in rural areas are rice farmer household as much as $43.17 \%$. Meanwhile for the amount of non-poor household in rural, rice farmer household thus ranked second with $26.64 \%$. It can be concluded that there is a gap between incomes of rice farmer households in rural areas.

Table 3 Adult Employment and Poor Status

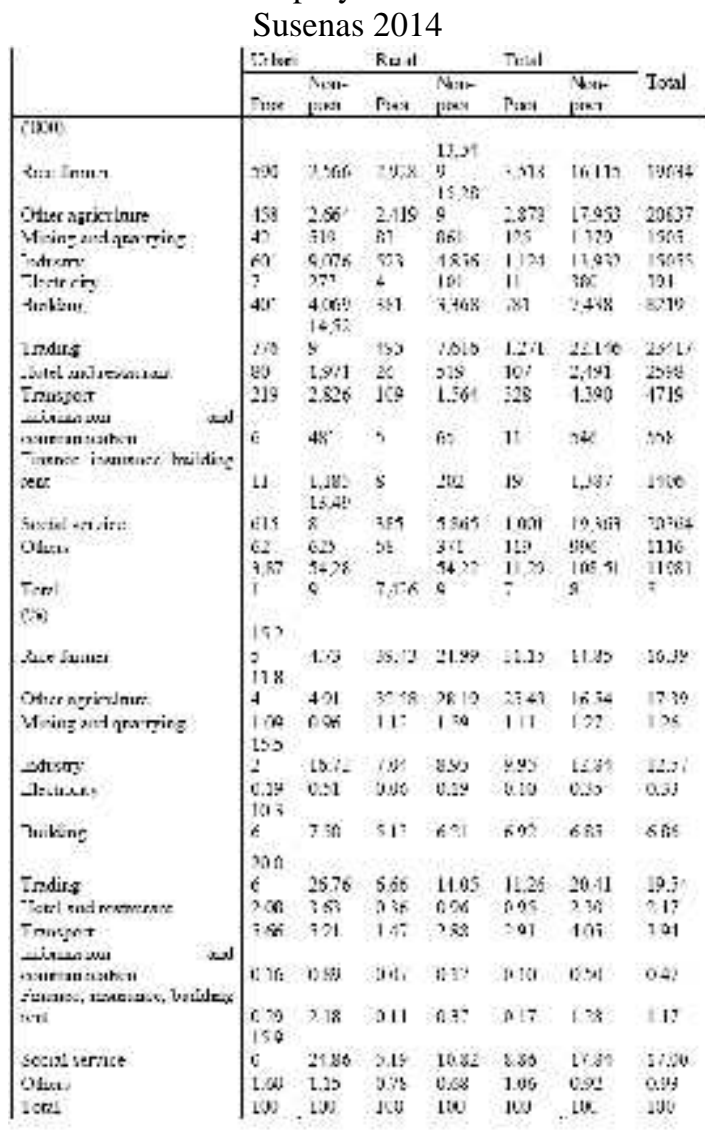

Source: Badan Pusat Statistik (2012)

On the third table shows the relationships between economic status and work field in urban and rural areas in 2014. The same thing is still shown in Table 3; there is still an anomaly in rural areas. Where most of poor households live in rural areas, they are occupied by the household who work as rice farmers 
as much as $39.43 \%$. For households in rural areas, amount of non-poor households are still occupied by rice farmers as much as $24.99 \%$. Any oddness is still shown in the rural areas, where from the result it can be predicted that the gap of income between rice farmers happened in the rural areas.

\section{Important Rice in the Household Expenditure}

Rice takes an important role in the household expenditure and it's explained by this graphs:

Figure 2 Household Expenditure

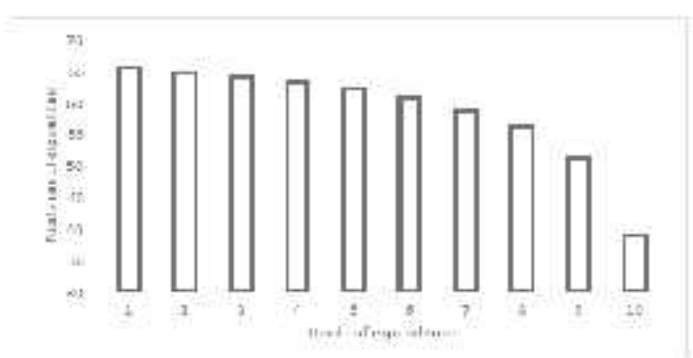

Source: Badan Pusat Statistik Rep of Indonesia (2012)

From the graph above, from scale 1 until 10 present us the preview of household wealth from the poorest to the richest. It shows that the poorer household has bigger expenditure on food. The poorest $1 \%$ spends around $65.57 \%$ on food which they consume monthly. On the other side richer household spend smaller amount of their income for food because they can afford it easily without being worry that they can't eat tomorrow.

Table 4 Household Expenditure by Location and Social Status

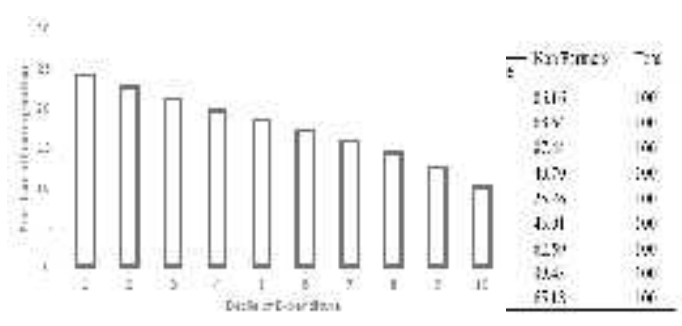

Source: Badan Pusat Statistik Rep of Indonesia (2012)

Share of rice consumption of food expenditure in household show us that poorer the households have higher tendencies to spent more on rice since in Indonesia rice has become main source of carbohydrate, which will be change into glucose that recharge energy. On the other side richer households tend to spend less on rice expenditure, because they can afford to get another source of carbohydrate like bread, wheat etc.

\section{Net Consumers}

In Table 4, it appears that in 2012 there were 5.61 million poor households consisting of $36.30 \%$ for rice farmers, other farmers $24.27 \%$ and $39.43 \%$ of non-farmers household. Meanwhile there is 50.27 million households are not poor. Only $17.26 \%$ is domestic rice farmers, other farmers $17.56 \%$, whereas $65.18 \%$ of non-farmers household.

Of all poor households in urban areas, $18.84 \%$ is domestic rice farmers another farmers $12: 52 \%$ and $68.64 \%$ of households are not farmers. $44.77 \%$ of the total poor households in rural areas are rice farmer households and about $29.97 \%$ are the other farmers and only $25.26 \%$ of non-farmers household. Only about $6.66 \%$ of total urban households who do not live in poverty and they are rice farming households. While in the countryside there are approximately $27.82 \%$ of farmers who are not poor households. In the group of 
non-poor households in rural areas, $27.82 \%$ is a rice farmer household, $29.17 \%$ are non-rice farming households and the remaining $43.01 \%$ isn't a farmer households.

In Table 5, it appears that of all rice farmer household, only $9.54 \%$ who are net producer while the remaining $90.55 \%$ is net consumer. It can be concluded that most of farmers household have to complete their needs of rice by buying at the large amount on the market or trading which determined by the market mechanism.

In urban areas there is only $3.45 \%$ of farmer household that are net producer and $96.46 \%$ net consumer. Meanwhile in rural area, there's $15.18 \%$ of farmer household that is net producer and $84.82 \%$ net consumer.

Table 5 Household Expenditure by Location and Social Status

\begin{tabular}{llll}
\hline & $\begin{array}{l}\text { Net } \\
\text { Producers }\end{array}$ & $\begin{array}{l}\text { Net } \\
\text { Consumers }\end{array}$ & Household \\
\hline Urban & 988427 & 26944971 & 27933398 \\
$(\%)$ & 3.54 & 96.46 & 100 \\
Rural & 4372958 & 24427255 & 28800213 \\
$(\%)$ & 15.18 & 84.82 & 100 \\
Total & 5361385 & 51372226 & 56733611 \\
$(\%)$ & 9.45 & 90.55 & 100 \\
\hline
\end{tabular}

Source: Badan Pusat Statistik Rep of Indonesia (2012)

Table 6. Net Producers and Net Consumers Susenas 2012

\begin{tabular}{|c|c|c|c|c|c|}
\hline & \multirow{2}{*}{$\begin{array}{l}\text { Total } \\
\text { Hoesehols } \\
\text { (indllines) }\end{array}$} & \multirow{2}{*}{$\begin{array}{l}\text { Tanowes } \\
\text { Rise }\end{array}$} & \multirow{2}{*}{$\begin{array}{l}\text { Non Fanmen } \\
\text { Ober } \\
\text { Agriculiner }\end{array}$} & \multicolumn{2}{|r|}{ Toeal } \\
\hline & & & & & \\
\hline Erban & 27.54 & $6.91 \%$ & 6.006 & 56.500 & $100 *$, \\
\hline Nover & 1.75 & 19.106 & 139.46 & 669046 & $100 \mathrm{t}$ \\
\hline $\begin{array}{l}\text { Neet } \\
\text { Roer }\end{array}$ & 26.69 & $6.08 \mathrm{~s}$ & sitons & stsest & $100 \%$ \\
\hline Rural & $3 a s e$ & $28.25 \%$ & 29889 & 41570 & $100 \%$ \\
\hline Roer & 3.3 & $41 * 4$ & $3200 \mathrm{k}$ & $25: 214$ & $100 \%$ \\
\hline $\begin{array}{l}\text { Neo } \\
\text { hoer }\end{array}$ & 26,74 & 26.616 & 206246 & 40.546 & $100 \mathrm{~s}$ \\
\hline Tetal & $57 . x 4$ & $17.956=$ & IE. $67 \%$ & 613386 & 10006 \\
\hline Poor & 508 & 33.826 & $25.6 \mathrm{~m}$ & ascens & $100 \mathrm{~s}$ \\
\hline $\begin{array}{l}\text { Nee } \\
\text { froer }\end{array}$ & $\mathrm{s}: 12$ & $16.47 \%$ & 180146 & 65529 & 100ts \\
\hline
\end{tabular}

Source: Badan Pusat Statistik Rep of Indonesia (2012)

In Table 6, we can see the percentage between the net consumers and net producers of rice in urban and rural areas in 2012. In urban there is a very significant difference between the number of households who are the net producers and net consumers of rice. There are only $3.54 \%$ of net producers households while net consumer households as much as $96.46 \%$ of the total households in the urban. We know that most of the rural households are the rice production households, but it turned out that the amount of net producer households only $15 \%$, while the $96.71 \%$ of households are still net rice consumers. That means their rice production is insufficient to the household's consumption of rice itself.

Table 7 Net Producers and Net Consumers Susenas 2014

\begin{tabular}{|c|c|c|c|}
\hline & $\begin{array}{l}\text { Net } \\
\text { Producers }\end{array}$ & $\begin{array}{l}\text { Net } \\
\text { Constrmers }\end{array}$ & Household \\
\hline Urban & $1,537,686$ & $29,456,438$ & $30,994,124$ \\
\hline (\%) & 4.96 & 95,04 & 100 \\
\hline Rural & $6,607,270$ & $25,478,411$ & $32,085,681$ \\
\hline$(\%)$ & 20.59 & 79,41 & 100 \\
\hline Total & $8,144.956$ & $54.934,849$ & $63,079,805$ \\
\hline \multirow[t]{3}{*}{$(\%)$} & 1291 & 87.09 & 100 \\
\hline & $\mathrm{N}=1$ & $\mathrm{~N}=1$ & \\
\hline & Prosinctos & Canisumety & Frounctioslt \\
\hline Erbas & $1.537,685$ & $29,456 . \div 28$ & 30.994 .124 \\
\hline$(\%)$ & 4.96 & 9505 & 100 \\
\hline Ruaral & $6.400,270$ & $25,476,-11$ & $32,085.681$ \\
\hline$(\%)$ & 20.59 & 79.41 & 100 \\
\hline Tomal & $8.14+955$ & $51,931,819$ & $62,079.805$ \\
\hline$(2 / n)$ & 12.91 & 87.09 & 100 \\
\hline
\end{tabular}

Source: Badan Pusat Statistik Rep of Indonesia (2012)

In table 7 we can see the percenttage between the net consumers and net producers of rice in urban and rural areas in 2014. It can be seen that the percentage of net producers households are increased to $4.96 \%$ while net household consumers as much as $95.04 \%$. In rural 
areas, there is an increase in the percentage of households who are net producers as much as $20,59 \%$ and $79.41 \%$ of households are still the net consumers of rice. Which means that most households in rural areas are still have to buy rice on the market with the prices that continues increased.

\section{RESEARCH METHOD}

\section{Simulation Using Equivalent Varia-} tion Calculation

Marshallian demand function are generated from simple Cobb-Douglass utility function:

$$
x_{p s}=\frac{m a}{P_{x}} \text {, and } y_{m i}=\frac{m_{i j}}{s_{y}} \text { (1) }
$$

Where $x_{\mathrm{m}}$ is the rice consumption and $y_{\mathrm{m}}$ are the others consumption. While, $m$ is the household expenditure, $\alpha$ is the share of rice on household expenditure, and $\beta$ is the share of others consumption on household expenditure. And, $P_{\mathrm{x}}$ id the rice price and $P_{\mathrm{y}}$ are the others price. From function above, authors can calculate the share of consumption rice in household:

$$
\alpha-\frac{c_{1,1} r_{x}}{m} \quad(\%)
$$

So, the indirect utility function can write as follow:

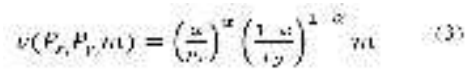

The minimum expenditure function can be:

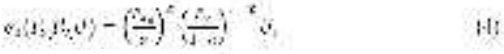

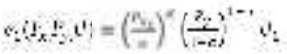

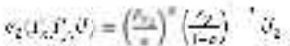

Where, $e_{0}$ is the minimum expenditure before price increasing. $e_{1}$ represents the minimum expenditure after the rice price increasing. And $e_{2}$ is the minimum expenditure after the rice price increasing but compensated with RAS-
KIN. So, Equivalent Variation can be calculated by:

$$
\begin{aligned}
& \overrightarrow{\nabla V_{1}}=v_{0}-v_{1} \\
& \underline{I} \hat{V}_{2}=v_{0}-\hat{c}_{2}
\end{aligned}
$$

$E V$ is the Equivalent Variation that show the amount of change of welfare, in this context is household consumption.

\section{DATA ANALYSIS AND DISCUSSION Poverty Incidence and Important of Raskin}

Figure 4 below shows us the result of simulation using increasing in the price of rice as the scenario. Rice price data obtained from Commodity Prices released by BPS. Changes in the price can be seen from January to December 2014.

Figure 4 Poverty Incidences by Province after Increasing Rice Price in 2014

$$
\text { Poverty Incidence }
$$

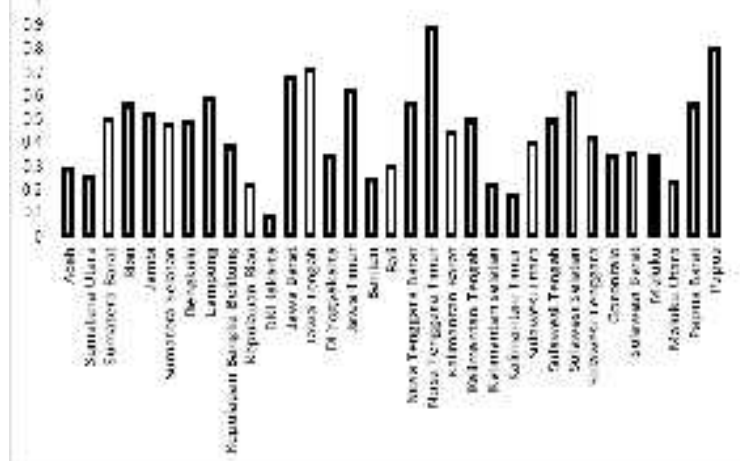

Source: Badan Pusat Statistik Rep of Indonesia (2012), proceed

Figure 5 Poverty Incidences by Province Urban and Rural after Increasing Rice Price in 2014

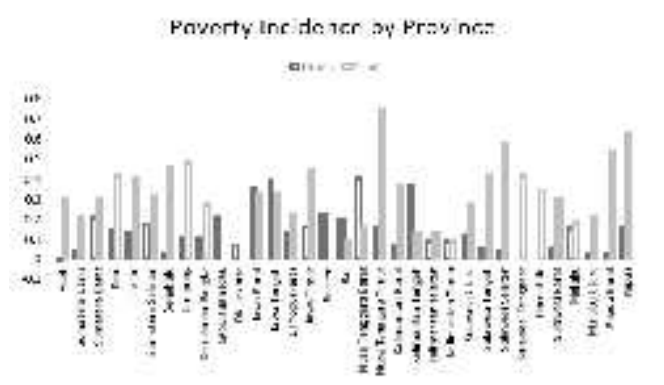


Source: Badan Pusat Statistik Rep of Indonesia (2012), proceed

On national estimation, the biggest impact of increasing on price of rice goes to NTT province (with 0.88 ) in eastern of Indonesia. NTT also got the first rank in rural sector estimation with 0.74 meanwhile on urban area the changes don't give much effect on the overall change. The second place after NTT is Papua with 0.79 on overall change in national estimation, thus they get the second trophy on rural sector estimation with change in rural 0.63 . On the third place on overall national estimation goes to Jawa Barat with 0.67, they also hit the same rank on urban area changes with 0.39. On the other hand Central Java placed second on urban changes, and Sulawesi Selatan hit the third place for rural area changes.

Figure 6 The Share of Equivalent Variation to Household Expenditure

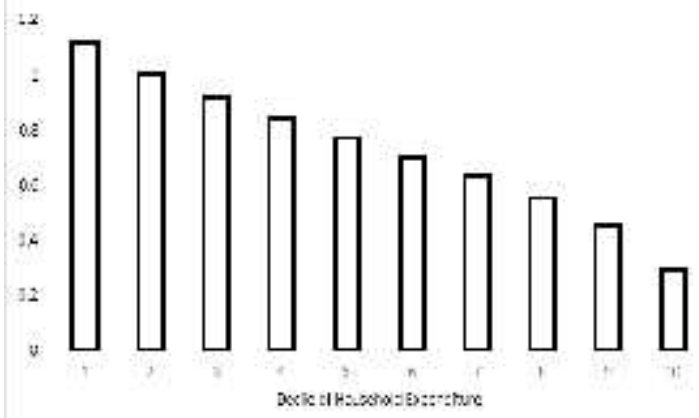

Source: Badan Pusat Statistik Rep of Indonesia (2012), proceed

The amount of EV indicates how much revenue is sacrificed to compensate for rising prices. When the price of rice is increasing, household will simultaneously adjust their consumption. EV value describes the consumption of goods whose sacrificed to cover the impact of the rising price of rice. The graph above shows the proportion of the value of EV to total household expenditure. It can be seen that poor households are affectted more than households with greater spending, ceteris paribus.

As an alternative, the authors also looked at the relationship between the proportion of EV in the total household expenditure and household characteristics. The author would like to see the statistical significance of equivalent variation simulation.

The simple econometric model: $E V i=X i+\epsilon i$ where $E V_{\mathrm{i}}$ is the share of $\mathrm{EV}$ to household expenditure, while $X_{\mathrm{i}}$ is the vector variables such as $\log$ of household expenditure, household size, rural location, RASKIN consumption, employment status, farmer status, and poor status.

Table 8 The Regression result from Share of EV to household expenditure model

\begin{tabular}{|c|c|c|}
\hline $\begin{array}{l}\text { Dependent: Share of FV to houschold } \\
\text { expeuditure }\end{array}$ & Coeflacien. & Sild envo: \\
\hline Log of houselsold expertidure & $-4.375 \mathrm{U}^{4: 82}$ & 0.0015 \\
\hline flousehold size & $0.0813^{10018}$ & 0.0005 \\
\hline Rural & $0.1052^{6+4}$ & 0.0018 \\
\hline Log of RASKIN & $0.0042^{20 * 3}$ & 0.0054 \\
\hline Wotk status & $0.0163^{\text {inks }}$ & 0,0021 \\
\hline Farmer & $0.0349+4$ & 0.0030 \\
\hline Pow & 0.2021 kat? & 0.0012 \\
\hline Constanta & $6.0314^{20: * 38}$ & 0.0232 \\
\hline \multicolumn{3}{|l|}{ Number of ubservalion $=235751$} \\
\hline \multicolumn{3}{|l|}{$1(39,236711)-4915.67$} \\
\hline $\mathrm{Prob}=\mathrm{F}$ & & \\
\hline K-squared $=0.140 .1$ & & \\
\hline
\end{tabular}

From the table above, it appears that the greater the wealth of a household, in this case is the level of consumption, the smaller the impact of the increase in rice prices, statistically significant. Poor variable is also statistically significant that shows poor households are affected more than the non-poor. Farmer households were also affected significantly compared to other households. Household with greater number of members are also affected more than 
household with smaller number of members. Household in the rural area suffered more than the urban area, and the most interest thing is that households who get Raskin are also significantly affected.

\section{CONCLUSION,IMPLICATION, SUGGESTION, AND LIMITATI- ONS}

Increasing rice price affects on consumers, especially for low-income consumers. Even though the rice farmers are as both rice producer and net consumer, they also buy rice in the market. Policy implication after this research are: Government must ensure the availability of food to make sure that the price of food does not soar, so the household shouldn't have to suffer especially poor household, import policy is a good decision in a short term, and in the long term Indonesia have to be able to increase domestic production.

\section{REFERENCES}

Mcculloch, N. (2015). Rice Prices and Poverty in Indonesia. Bulletin of Indonesian Economic Studies: Australia.

Patunru, A. A. (2015). Trade Protectionism in Indonesia: Bad Times and Bad Policy. Lowy Institute: Australia.

Susenas (2012, 2014), Badan Pusat Statistik (BPS), microdata.bps.go.id accessed March $4^{\text {th }}$ March 2016

Warr, P., \& Yusuf, A. A. (2013). World Food Prices and Poverty in Indonesia. The Australian Journal of Agricultural and Resource Economics: Australia. 